\title{
ENERGY BALANCE AND EFFICIENCY IN WOOD SAWDUST BRIQUETTES PRODUCTION
}

\author{
Luiz Vicente Gentil ${ }^{1}$; Ailton Teixeira Vale ${ }^{2}$ \\ ${ }^{1}$ University of Brasília, Federal District, Brazil - lvgentil13@gmail.com; ailton.vale@gmail.com \\ Received for publication: 27/06/2013 - Accepted for publication: 14/11/2014
}

\begin{abstract}
The industrial wood briquette making process is an alternative to add value to forestry waste and involves the compaction of sawdust at high pressure and temperature. The present study was performed in an industry in the state of Goiás, Brazil. All kinds of energy involved in the wood briquette manufacturing process were qualified and quantified, in all stages of the process. The methodology used was based on Cotrim (1992), Silva (2001), (BEN, 2007), Inconprera (2008) and NBR 8633. The total energy demand to produce one ton of Pinus wood briquettes using sawdust at $43.8 \%$ moisture was $435 \mathrm{kWh}$. When producing the same amount of briquettes at $11 \%$ humidity, this value fell to $101.66 \mathrm{kWh}$ per ton. Thus, drying process of sawdust consumes $76.63 \%$ of all the energy used for manufacturing. The amount of energy required for the production of 1 ton of briquettes corresponds to $10.8 \%$ (wet sawdust) and $4.37 \%$ (dry sawdust) of the energy contained in this one ton of briquettes.

Keywords: Wood densification; industry of briquette; energy.
\end{abstract}

\section{Resumo}

Eficiência e balanço energético na fabricação de briquetes de madeira. A briquetagem é uma alternativa para agregar valor a resíduos de origem agro florestal e consiste na compactação da serragem a elevadas pressões e temperatura. Este trabalho foi desenvolvido em uma indústria no estado de Goiás, onde foram quantificadas e caracterizadas todas as energias envolvidas no processo de fabricação de briquete em todas as etapas do processo industrial. A metodologia utilizada baseouse em Cotrim (2003), Silva (2001), Brasil (2007), Inconprera (2008), ABNT (1984). A unidade utilizada foi $\mathrm{kWh} / \mathrm{t}$ de briquete fabricado. A demanda total de energia para fabricar uma tonelada de briquete a partir de serragem de Pinus com $43,8 \%$ de umidade foi de $435 \mathrm{kWh} / \mathrm{t}$. Quando se fabrica a mesma a quantidade de briquetes agora com umidade de $11 \%$, este valor cai para 101,66 $\mathrm{kWh} / \mathrm{t}$. Assim, a secagem da serragem consome $76,63 \%$ de toda energia de fabricação. Entretanto com a serragem a $11 \%$ de umidade a maior demanda de energia eletricidade, com $64,06 \%$. A energia necessária para produzir uma tonelada de briquete com serragem úmida $(43,8 \%)$ corresponde a $10,8 \%$ da energia contida nesta 1 tonelada de briquete e com serragem seca a 4,37\%.

Palavras-chave: Briquetagem de madeira; indústria de briquete; energia.

\section{INTRODUCTION}

Wars and energy crises have always been reasons to look for alternative energy sources, both for the possibility of supply interruptions and for the increase of oil price. More recently, concerns with environment also entered the list of motives. There is a consensus that environment is being polluted by air, soil and waters overall the planet, giving birth to a global consciousness aimed to reduce pollution in order to guarantee survival of societies (ITERGOVERNAMENTAL PANEL ON CLIMATE CHANGE (IPCC), 2007). This environmental consciousness generated the necessity to reduce fossil fuels consumption and caused intensive use of bioenergy aiming to reduce the greenhouse effect (PERSSON, 2006).

Alternative sources of energy grew with more emphasis since the Second World War, in 1941, not only because of the demographic explosion, but also thanks to the technological development all over the western world, asking for more energy. Thus, there were an increased number of studies on energy involving biomass, electric technology, wind, water, sun, atom and hydrogen as possible sources, among

FLORESTA, Curitiba, PR, v. 45, n. 2, p. 281 - 288, abr. / jun. 2015.

Gentil, L. V.; Vale, A. T.

ISSN eletrônico 1982-4688 / ISSN impresso 0015-3826 
others. As well as there is a worldwide tendency to concentrate on electric cogeneration with biomass where it is abundant, of good quality and low price (GOLDEMBERG, 1998; LOPES et al. 2000; PATUSCO, 1993).

Thus, in this context, there is the possibility of partial substitution of the oil energy matrix with alternative energies, including biomass. Biomass was conceived as one of the alternatives to fossil fuels because of its environmental characteristics, renewable at each plantation, with low price, abundant and with a production potential limited by the available crops in the planet (ROSSILO-CALE, 2004; TABARÉS, 2000; GOLDEMBERG, 1998). Cellulosic woods, generated by native or cultivated trees, are among the most promising types of biomass, with the higher levels of low cost energy.

An alternative use of biomass is briquetting, which is densification of agro-forestry residues into high energy density briquettes. Densification, to produce briquettes, consists in compacting sawdust at high pressures, causing temperature increases of the sawdust itself. Because of the high pressures involved in briquetting, lignin contained in sawdust, which is a thermoplastic polymer, starts a sintering process between $80^{\circ} \mathrm{C}$ and $200{ }^{\circ} \mathrm{C}$, depending on the type of cellulosic wood material, acting as binder of the wood particles (PAULARD, 2004; ROWELL, 1999).

Briquettes are used to generate heat and power in industrial furnaces or in civil market like bakeries and pizzerias. Estimated production of wood residues per year in Brazil is 14 million of tons, with an energetic potential of $173 \mathrm{PJ}$ or 4,132 x $10^{6}$ tep (GENTIL, 2008). If those wood residues, defined by Alves (2000) as parts of broken logs not transformed in commercial sawn wood, including slabs, chips, discarded and short wood pieces, sawdust and bark, were transformed in briquettes, there would be greater income, more jobs and regional development in Brazil.

Industrial processes in general are different, according to the economy and culture of every country, depending on climate, type of available raw matter, technology and qualification of workers, type of compacting machines and demands of the market (TRIPHATI et al., 1998; QUIRINO, 1991).

Triphati et al. (1998), Alakangas (2002) Hirsmark (2002) affirm that industrialization of briquettes generally follows basic steps like drying of raw matter, milling, sieving, densification and cooling. In a general way, industries in Brazil apply the following industrial steps: 1) densification, 2) drying, 3) sieving, 4) cooling, 5) comminution. Other important steps are in general not reported in scientific works, as pre-processing steps, post-processing steps, storage, packaging, administration/sales/marketing, ensiling of the raw matter or delivery.

This work aimed to verify the hypothesis that drying of humid biomass significantly increases consumption of energy during the briquetting process. The objective of this work was to investigate quantity and quality of energy used and the efficiency of the wood briquettes production process in a plant in Goiás state, considering eight steps in the production process and five types of energy used.

\section{MATERIAL AND METHODS}

Data were collected in a wood briquettes production plant located in the State of Goiás, with a monthly production of 650 tons, a daily production time of 14 hours, 21 employees and 2 briquetting machines with piston pulse system for sawdust raw material compacting process. Electric energy was supplied by the local provider through a tri-phasic connection at $13,800 \mathrm{~V}$, lowered using a $150-\mathrm{kVA}$ transformer. Power was provided by 29 tri-phasic electric motors connected to five distribution panels. Motors were equipped with capacitors banks to maintain the power factor $(\cos \varphi)$ equal or above $93 \%$. Exhaustion, sieving and briquetting equipment used frequency inverters to control speed of motors and consequently flow of dry and humid sawdust of briquettes.

\section{Relation between energy used for production and energy contained in briquettes $(\eta)$}

Relation between energy used for production and energy contained in the briquette was determined by equation 1 .

$$
\eta=\frac{100 * \xi_{1}}{\xi_{2}}
$$

where: $\xi_{1}$-energy needed to produce one ton of briquettes $(\mathrm{kWh})$;

$\xi_{2}$-calorific energy contained in one ton of briquettes $(\mathrm{kWh})$. 
To determine the amount of energy needed to produce one ton of briquettes, all types of energy involved, electric, chemical, human and thermic were considered.

\section{Electric energy}

Consumption of electric energy was divided in two types: electric energy consumed directly in the production of briquettes by 24 motors (EE) and electric energy considered as support (EA), consumed by 5 motors used for air compression, loading belt for trucks, water pump and by two fans. Power in each of the 29 electric motors was measured using a Nanovip digital wattmeter, according to Cotrim (2003) and equation 2 .

$$
P e=\frac{V^{*} A * \sqrt{3 * \cos \varphi}}{1000}
$$

where: Pe-power ( $\mathrm{kW}), \mathrm{V}$-tension in volts; A-current (ampere);

$\sqrt{3}$-correction factor for three phase motors;

$\cos \varphi$ - power factor.

\section{Human energy}

Estimate of human energy consumption (EH) was based on Silva (2001) and the equation 3.

$$
E h t=E D * D T * N F * 10^{-6}
$$

where: Eht-total human energy (MJ/month);

ED-15.884 J/day (SILVA, 2001);

DT-working days per month;

NF-number of employees in the industrial process

\section{Chemical energy (EQ):}

The requirement of chemical energy (EQ) was based on diesel oil consumption of the tractor and trucks, according to Silva (2001) and the equation 4.

$$
E Q=Q C^{*} P C^{*} M E^{*} 10^{-3}
$$

where: EQ-chemical energy (Mcal/month); QC-volume of diesel oil per month (1);

PC-superior calorific power of the diesel oil equal to 44,935 kJ/kg (BRASIL, 2007);

ME-specific mass of the diesel oil equal to $0,852 \mathrm{~kg} / \mathrm{liter}$ (BRASIL, 2007).

\section{Thermic energy (ET)}

Equation 5 was written to estimate the quantity of thermic energy required as heat to dry sawdust, according to Incropera (2003).

$$
Q_{S}=\frac{Q_{S, \text { bio }}+Q_{S, \mathrm{H}_{2} \mathrm{O}}+Q_{L, \mathrm{H}_{2} \mathrm{O}}}{V_{m, \text { briq. }}}
$$

where: $Q_{s}$-quantity of heat required to dry humid sawdust $(\mathrm{Gj} / \mathrm{t}$ of briquettes);

$\mathrm{Q}_{\mathrm{s}, \text { bio }}$-sensible quantity of heat of the dry sawdust entering the drier $(\mathrm{Gj} / \mathrm{hour})$;

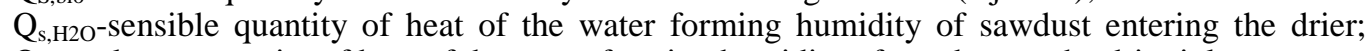

$\mathrm{Q}_{\mathrm{L}, \mathrm{H} 2 \mathrm{O}}$-latent quantity of heat of the water forming humidity of sawdust, at the drier inlet;

$\mathrm{V}_{\mathrm{m}, \text { briq }}$-mass flow of the finished briquette $(\mathrm{t} / \mathrm{h})$.

Determination of the $\mathrm{Q}_{\mathrm{s}, \mathrm{bio}}$ energy portion, by equation 6 .

$$
Q_{S, b i o}=M_{\text {bio }} * C * \Delta T
$$

where: $\mathrm{M}_{\text {bio }}$-mass of the dry biomass $(\mathrm{kg} / \mathrm{h})$;

C-specific heat of sawdust $\left(1.25 \mathrm{~kJ} / \mathrm{kg}^{\circ} \mathrm{C}\right)$;

$\triangle \mathrm{T}$-temperature variation $\left({ }^{\circ} \mathrm{C}\right)$ of biomass, from the entrance in the drier until vaporization point, assuming constant the internal pressure of the drier $(1.0 \mathrm{~atm})$.

FLORESTA, Curitiba, PR, v. 45, n. 2, p. 281 - 288, abr. / jun. 2015.

Gentil, L. V.; Vale, A. T.

ISSN eletrônico 1982-4688 / ISSN impresso 0015-3826 
Determination of the $\mathrm{Q}_{\mathrm{s}, \mathrm{H} 2 \mathrm{O}}$ energy portion, by equation 7 .

$$
Q_{S, \mathrm{H}_{2} \mathrm{O}}=M_{\mathrm{H}_{2} \mathrm{O}} * C_{P} * \Delta T_{\mathrm{H}_{2} \mathrm{O}}
$$

where: $\mathrm{M}_{\mathrm{H} 2 \mathrm{O}}$-mass of evaporated water between entrance and exit of the drier $(\mathrm{kg} / \mathrm{h})$;

$\mathrm{C}_{\mathrm{p}}$-specific heat of sawdust, assumed as $4.19 \mathrm{kj} /{ }^{\circ} \mathrm{C}$, at constant pressure;

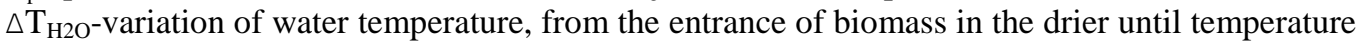
of evaporation of $100{ }^{\circ} \mathrm{C}(1.0 \mathrm{~atm})$.

Determination of the $\mathrm{Q}_{\mathrm{L}, \mathrm{H} 2 \mathrm{O}}$ energy portion, by equation 8 .

$$
Q_{L, \mathrm{H}_{2} \mathrm{O}}=M_{\mathrm{H}_{2} \mathrm{O}} * L
$$

where: L-latent heat of water, equal to $2,257 \mathrm{~kJ} / \mathrm{kg}$

\section{Calorific energy contained in the briquette}

The Gross Calorific Power (PCS) of briquette at $0 \%$ humidity was determined according to the norm NBR 8633 (ASSOCIAÇÃO BRASILEIRA DE NORMAS TÉCNICAS (ABNT), 1984), with a calorimeter type "Ika C2000 basic". The Net Calorific Power (PCI) of briquette at $0 \%$ humidity was determined by equation 9 , and the available calorific power (PCU) of the briquette at $12.9 \%$ humidity by equation 10 , in $\mathrm{kJ} / \mathrm{kg}$

$$
P C I=P C S-\left(2.508 * \frac{9 h}{100}\right)
$$

where: h-hydrogen content $(\%)$

$$
P C U=P C I_{0 \%} *(1-U)-2.508 * U
$$

where: U-Humidity in humid base (\%).

Ten steps were studied in the process of the considered plant: 1) pre-process (transport and storage of the raw matter), 2) sieving (continuous rotational sieve), 3) drying of sawdust (oven and rotational drier), 4) exhaustion (cyclone to cool raw matter down), 5) briquetting (mechanical briquetting machine with pulse pressure piston), 6) storage (in $15 \mathrm{~kg}$ or $35 \mathrm{~kg}$ bags), 7) sales and administration, 8) dispatching and delivery of the finished product.

Briquettes were produced with sawdust of Pinus $s p$ with the following characteristics: $30 \mathrm{~cm}$ length, diameters from $8.5 \mathrm{~cm}$ to $9.5 \mathrm{~cm}$, bulk density of $1,060 \mathrm{~kg} / \mathrm{m}^{2}$, granulate density of $692 \mathrm{~kg} / \mathrm{m}^{3}$, humidity of the humid base $43.8 \%$, granulate size varying from $0.84 \mathrm{~mm}(48 \%)$ to $3.35 \mathrm{~mm}(15.57 \%)$, ash content of $1.99 \%$ and gross calorific power of $18.37 \mathrm{GJ} / \mathrm{t}$.

\section{RESULTS AND DISCUSSION}

\section{Steps in the fabrication process of briquettes}

- Pre-process -activity involving transportation of raw matter to the plant, consuming chemical, human and support energy.

- Sieving - One of the employees transports sawdust from storage to the belt feeding the sieving station, which is a sieve-type revolving cage, separating residues burned into the drier oven.

- Drying - During the drying process, humidity of sawdust was reduced to about $11 \%$, is performed by three equipment, all of them consuming chemical, human, thermic, electric and support energy

Oven - Masonry chamber with refracting brick type, with temperature varying from $323^{\circ} \mathrm{C}$ and $563{ }^{\circ} \mathrm{C}$, fed with wood residues, sieving residues and unused briquettes.

Blower - has the purpose to keep combustion with excess of air inside the oven, to maintain high efficiency of combustion 
Dryer - Metallic, cylindrical, horizontal, rotating, with $1.8 \mathrm{~m}$ diameter and 12 meter length, total volume of 21 cubic meters.

- Exhaustion - besides extracting hot air from the oven at a rate of $9 \mathrm{~m}^{3} / \mathrm{s}$, the exhauster lowers temperature of sawdust exiting the drier and swipes away thin particles, undesirable for the briquetting process. During exhaustion, chemical, electric, human and support energy are consumed. Between exhauster and briquetting machine, sawdust is stored in a masonry box with capacity of $12.9 \mathrm{~m}^{3}$, keeping the average temperature at $43^{\circ} \mathrm{C}$.

- Briquetting - two briquetting machines with pulse pressure piston, one is Hansa model, with nominal capacity of $1,200 \mathrm{~kg} / \mathrm{h}$ and another is a Biomax type, with nominal capacity of $800 \mathrm{~kg} / \mathrm{h}$. They are responsible for densification of sawdust with $11 \%$ humidity content. Briquetting process consumes chemical, human, electric and support energy. During the production process, temperature of briquettes reaches $250{ }^{\circ} \mathrm{C}$ and then they are cooled down to $60{ }^{\circ} \mathrm{C}$, when they are packaged.

- Storage - Briquettes are packaged in $15 \mathrm{~kg}$ and $35 \mathrm{~kg}$ bags, and stacked in 2 to 4 meter high piles.

- Shipping - Loading of trucks using a conveyor belt.

\section{General energy demand in all the production steps}

Table 1 shows energy demand of each production step and the total demand to produce one ton of briquettes. Considering the five types of energy and eight production steps, total demand of energy is $435 \mathrm{kWh}$ per ton of finished briquettes. Bhattacharva (2002), studying production of rice hull briquettes in Thailand and using a screw press, found values of $111 \mathrm{kWh} / \mathrm{t}$ and $179 \mathrm{kWh} / \mathrm{t}$ of finished briquettes, without considering thermic energy. Studying "pellets" produced in Sweden and Austria, Thek and Obernberger (2002) found energy demands respectively of $137 \mathrm{kWt} / \mathrm{t}$ and $179 \mathrm{kWt} / \mathrm{t}$. The big energy demand found in this work, to produce one ton of briquettes, is due to necessity of the drying process on sawdust delivered to the plant with $43.8 \%$ of humidity content.

Table 1. Energy demand for one ton of briquettes using sawdust with high humidity content $(\mathrm{kWh} / \mathrm{t})$.

Tabela 1. Demanda de energia para produção de uma tonelada de briquete com serragem com elevada umidade $(\mathrm{kWh} / \mathrm{t})$

\begin{tabular}{lccccccc}
\hline \multirow{2}{*}{ Steps } & \multicolumn{9}{c}{ Energy } & \multicolumn{2}{c}{$\begin{array}{c}\text { Participation } \\
(\boldsymbol{\%})\end{array}$} \\
\cline { 2 - 8 } & Electric & Thermic & Chemical & Human $\left(\mathbf{x 1 0}^{-4}\right)$ & Electric support & Total & 0.37 \\
Pre-process & 0.00 & 0.00 & 8.73 & 4.88 & 9.10 & 2.09 \\
Sieve & 2.21 & 0.00 & 3.75 & 3.25 & 1.86 & 7.83 & 1.80 \\
Drier & 3.30 & 333.33 & 2.85 & 4.88 & 2.49 & 341.97 & 78.62 \\
Exhaust & 9.88 & 0.00 & 0.56 & 1.63 & 1.86 & 12.3 & 2.83 \\
Briquetting & 49.73 & 0.00 & 1.49 & 6.51 & 3.73 & 54.95 & 12.63 \\
Storage & 0.00 & 0.00 & 0.00 & 1.63 & 0.25 & 0.25 & 0.06 \\
ADM and sales & 0.00 & 0.00 & 0.00 & 0.00 & 1.24 & 1.24 & 0.28 \\
Shipping & 0.00 & 0.00 & 6.74 & 0.00 & 0.62 & 7.36 & 1.69 \\
\hline Total & 65.12 & 333.33 & 24.12 & 22.78 & 12.43 & 435.00 & 100.00 \\
Participation (\%) & 14.97 & 76.63 & 5.54 & & 2.86 & 100.00 & \\
\hline
\end{tabular}

The total amount of energy for densification of biomass in the industrial process, according to Tripathi et al. (1998), depends on humidity and particle size of the raw matter, flow and density of the briquette, type of machine, wood to be milled or scale regime. In the case of this work, the most impacting factor is the high humidity content, which takes to a high consumption of energy in the drying process, which is the step with the highest energy demand equal to $333.33 \mathrm{~kW} / \mathrm{t}$, and corresponds to $76.6 \%$ of the total energy consumed in all steps.

However, not considering the thermic energy, in other words considering sawdust arriving to the plant with low humidity contents, as is the case of sawdust originated from furniture fabrication, energy participations change as shown in table 2 .

Table 2 shows that the total demand of energy to produce one ton of briquettes from raw matter with adequate humidity content for the process, not needing any drying process, is $101.66 \mathrm{kWh} / \mathrm{t}$, from four types of energy and eight production steps. The most energy-demanding step is then the briquetting process with $54.05 \%$ and the most important type of energy is the electric, with $64.06 \%$. This step has the

FLORESTA, Curitiba, PR, v. 45, n. 2, p. 281 - 288, abr. / jun. 2015.

Gentil, L. V.; Vale, A. T.

ISSN eletrônico 1982-4688 / ISSN impresso 0015-3826 
biggest energy demand because it uses the biggest electric motors, $50.75 \mathrm{~kW}$ and $62.52 \mathrm{~kW}$, totalizing $113.27 \mathrm{~kW}$ of energy installed and consuming $65.12 \mathrm{~kW} / \mathrm{t}$ of finished briquettes.

Table 2. Demand for energy to produce one ton of briquettes using sawdust at $11 \%$ humidity $(\mathrm{kWh} / \mathrm{t})$.

Tabela 2. Demanda de energia para produção de uma tonelada de briquete com serragem seca a $11 \%$ de umidade $(\mathrm{kWh} / \mathrm{t})$.

\begin{tabular}{lcccccc}
\hline \multirow{2}{*}{ Steps } & Electric & Chemical & $\begin{array}{c}\text { Human } \\
\left(\mathbf{x} 10-\mathbf{4}^{\mathbf{4}}\right)\end{array}$ & $\begin{array}{c}\text { Electric } \\
\text { support }\end{array}$ & Total & $\begin{array}{c}\text { Participation } \\
(\boldsymbol{\%})\end{array}$ \\
\cline { 2 - 7 } & 0.00 & 8.73 & 4.88 & 0.37 & 9.10 & 8.95 \\
Pre-process & 2.21 & 3.75 & 3.25 & 1.86 & 7.82 & 7.70 \\
Sieve & 3.30 & 2.85 & 4.88 & 2.49 & 8.64 & 8.50 \\
Drier & 9.88 & 0.56 & 1.63 & 1.86 & 12.30 & 12.10 \\
Exhaust & 49.73 & 1.49 & 6.51 & 3.73 & 54.95 & 54.05 \\
Briquetting & 0.00 & 0.00 & 1.63 & 0.25 & 0.25 & 0.25 \\
Storage & 0.00 & 0.00 & 0.00 & 1.24 & 1.24 & 1.22 \\
ADM and sales & 0.00 & 6.74 & 0.00 & 0.62 & 7.36 & 7.24 \\
Shipping & 65.12 & 24.12 & 22.78 & 12.43 & 101.66 & 100.00 \\
\hline Total & 64.06 & 23.72 & 0.00 & 12.23 & 100.01 & \\
Participation $(\%)$ & & & & & & \\
\hline
\end{tabular}

\section{General analysis of the energy demand}

Results confirmed data taken from literature, in other words, in the production process of briquettes made from raw matter with humidity content above the ideal values (between $8 \%$ and $12 \%$ ), the energy demand increases depending on the necessary drying process and thus on increased demand for thermic energy. In the working conditions it is observable a difference of $232.67 \mathrm{kWh} / \mathrm{t}$ between briquettes produced with dry sawdust and very humid sawdust, in other words $228 \%$. Considering humidity reduction from $43.8 \%$ to $11 \%$ in the drying process, each $1 \%$ of humidity variation required $7.06 \mathrm{kWh} / \mathrm{t}$ of briquettes.

The briquetting machine, the one with installed power of $50.75 \mathrm{~kW}$, had exact energy requirement of $50.75 \mathrm{~kW}$, in other words with an efficiency of $100 \%$ at the maximum limit and zero reserve. The other briquetting machine, with installed power of $62.52 \mathrm{~kW}$, required $38 \mathrm{~kW}$ or just $60.8 \%$ of the available power. It is true that, on the one hand, there is room for an extra electric load; on the other hand, this motor is oversized. In the sawdust cooling process, the electric energy demand of the cyclone motors set at $15.2 \%$.

Chemical energy demand (diesel oil) corresponds to transportation of raw matter from sawmill to the plant $(36.2 \%)$ and shipping of the finished product to the customer (27.9\%). Pre-process and postprocess summarize $64 \%$ of the total, with sieving at the third place at $15.6 \%$ and relative to movement of tractors transporting sawdust in and out the plant.

Human energy demand in the industrial process is very little. However, among the production steps, the biggest demand is from briquetting and corresponds to labor for packaging, movement and maintenance of the densification machines, with $28.6 \%$ of the human energy demand. The other big parcel of human energy, $21.4 \%$, represents workers involved with loading and unloading trucks with raw matters, and loading the finished product.

The plant has 24 electric motors used for production and five more working in general indirect support, as motors for air compression, loading of trucks, water pump, fan of the water tank and administration, demanding $12.5 \mathrm{kWh} / \mathrm{t}$ or $2.86 \%$ of the total of $435 \mathrm{kWh} / \mathrm{t}$.

\section{Relation between energy demand for production and energy contained in 1 ton of briquettes}

Energy demand to produce 1 ton of briquettes was $435 \mathrm{kWh}$ and the caloric energy content of a briquette with $12.9 \%$ humidity was $4,026.7 \mathrm{kWh} / \mathrm{t}$, in other words, the quantity of energy used to produce 1 ton of briquettes corresponds to $10.8 \%$ of the energy contained in this same 1 ton. Considering sawdust with $11 \%$ humidity content, the energy demand to produce 1 ton of briquettes falls from 435 to 101.66 $\mathrm{kWh} / \mathrm{ton}$, in other words $4.37 \%$ of the energy contained in the briquette. Mani et al. (2003), studying wood in British Columbia, Canada, found values of $22 \%$ of industrial energy to produce one ton of "pellet" considering the energy contained in the sawdust used to produce them. Quirino (2002) recorded 
$4.85 \%$ in production of briquettes; Hirsmark (2002) found $13 \%$ of energy demand with relation to potential energy of wood. Difference between values in study and the ones found in literature may depend on humidity content.

\section{CONCLUSIONS}

- Fabrication process of briquettes presents an high level of industrial automation and technology, with little demand of human energy,

- The use of humid sawdust, coming for example from processing of timber in sawmills, increases the energy consumption due to the necessary drying process to reach from $8 \%$ to $15 \%$ of humidity content,

- Sawdust coming from the production process of furniture, for example, arrives at the briquetting plant with adequate humidity content for the process and because of that, the energy demand falls by $76.6 \%$, value that corresponds to the demand of thermic energy to dry sawdust, in other words, $333.33 \mathrm{kWh}$ per ton of finished product,

- When considering the use of already dried sawdust originated from dry residues of furniture industries, electric energy demand is $64.06 \%$ of all the energy used for fabrication, with the value of $65.12 \mathrm{kWh} / \mathrm{t}$,

- Chemical energy demand in form of diesel oil consumed by trucks suggests the importance of raw matter and finished product transport compared to the other energy requirements for briquette fabrication,

- Quantity of energy necessary to produce one ton of briquettes corresponds to $10.8 \%$ of the energy contained in this 1 ton of briquettes, when using humid sawdust, falling to $4.37 \%$ when dry sawdust is used.

\section{REFERENCES}

ASSOCIAÇÃO BRASILEIRA DE NORMAS TÉCNICAS (ABNT) NBR 8633 - Carvão vegetal: determinação do poder calorífico. Rio de Janeiro: ABNT. 1984. 13 p.

ALAKANGAS, E.; PAJU, P. Wood pellets in Finland - Technology, economy and market. OPET Report5. Jyvaskyla. VTT Processes, 2002. 64 p.

ALVES, C. G. Rendimento de desdobro de toras, geração de resíduos e tempo de trabalho em serraria na Amazônia: o estudo de caso da Mil Madeireira, Itacoatiara - AM. 103 p. Dissertação (Mestrado em Ciências de Florestas Tropicais) - Universidade da Amazônia, Manaus, 2000.

BRASIL - MINISTÉRIO DE MINAS E ENERGIA. Balanço Energético Nacional 2007: Ano base 2006. Empresa de Pesquisa Energética - Rio de Janeiro: EPE, 2007. 192 p.

BHATTACHARYA, S. C.; AUGUSTUS LEON, M.; RAHMAM, M. A study on improved biomass briquetting. Asian Institute of Techolology. Thailand, v. 6, n. 2. 2002.

COTRIM, A. A. M. B. Instalações elétricas. São Paulo: Prentice Hall, 4. ed. 678 p. 2003.

GENTIL, L. V. B. Tecnologia e economia do briquete de madeira. 195 p. Tese (Doutorado em Ciências Florestais) - Departamento de Engenharia Florestal. Faculdade de Tecnologia. Universidade de Brasília, Brasília-DF, 2008.

GOLDEMBERG, J. Energia, meio ambiente e desenvolvimento. São Paulo: Ed. Edusp, 1.ed. 234 p. 1998.

HIRSMARK, J. Densified Biomass Fuels in Sweden. Swedish University of Agricultural Sciences. Department of Forest Management and Products. Sveriges lantbruksuniversitet. Institutionen för skogshushållning. Examensarbeten nr. 38. 83 p. Uppsala, Sweden. 2002.

INCONPRERA, F. Fundamentos de transferência de calor e massa. Rio de Janeiro: Ed. LTC - Livros Técnicos e Científicos, $6^{\text {a }}$ ed. 643 p. 2008.

FLORESTA, Curitiba, PR, v. 45, n. 2, p. 281 - 288, abr. / jun. 2015.

Gentil, L. V.; Vale, A. T.

ISSN eletrônico 1982-4688 / ISSN impresso 0015-3826 
INTERGOVERNMENTAL PANEL ON CLIMATE CHANGE (IPCC). Climate Change 2007: The Physical Science Basis. Solomon, S., D. Qin, M. Manning, Z. Chen, M. Marquis, K.B. Averyt, M. Tignorand H.L. Miller (eds.)]. Cambridge University Press, Cambridge, United Kingdom and New York, NY, USA. 996. 2007.

LOPES, R. P.; OLIVEIRA FILHO, D.; DONZELES, S. M. L. Controle da combustão em fornalhas a lenha.. In: ENCONTRO DE ENERGIA NO MEIO RURAL, 3., 2000, Campinas. Proceedings on line... Available from: <http://www.proceedings.scielo.br/scielo.php?script=sci_arttext\&pid=MSC0000000022 000000200023\&lng=en\&nrm=abn>. Acesso em: 14 Feb. 2014.

MANI, S.; TABIL, L. G.; SOKHANSANI, S. An overview of compaction biomass grinds. Powder Handling and Processing. v. 15, n. 3, p. 160 - 168. 2003.

PAULRUD, S. Upgraded Biofuels - Effects of Quality on Processing, Handling Characteristics, Combustion and Ash melting. 53 p. Doctoral thesis (Swedish University of Agricultural Sciences). Umeå. Sweden, 2004.

PATUSCO, J. A. M. Tratamento da Cogeração nos Balanços Energéticos. COBEN 08/93. 1993. Disponível em http://www.aneel.gov.br.

PERSSON, G. Speech at World Bionergy 2006. Proceedings. $2^{\mathrm{d}}$ World Conference on Pellets.Ed. Sverbio. Jonkoping. 2006.

QUIRINO, W. F. Briquetagem de resíduos ligno-celulósicos. Laboratório de Produtos Florestais. Serviço Florestal Brasileiro. IBAMA - Circular Técnica. v. 1, n. 2.10 p. Brasília-DF. 1991. Disponível em: www.funtec.org.br/arquivos/briquetagem.pdf. Acesso em 25/02/2014.

QUIRINO, W. F. Utilização energética de resíduos vegetais. Laboratório de Produtos Florestais. LPF/IBAMA. Brasília - DF. 35 p. 2002.

ROSSILO-CALLE, F. Uma breve análise do potencial da biomassa no Brasil. Biomassa \& Energia, v. 1, n. 3, 225 - 236. 2004.

ROWELL, R. M. Specialy treatments.Chapter 19, 34 p. In: Wood Handbook - wood as an engineering material. Forest Products Laboratory.USDA - Forest Service.General Technical Report FPL-GTR-113. Madison, Wisconsin. 486 p. 1999.

SILVA, D. A. Avaliação da eficiência energética de uma indústria de painéis compensados. 205 p. Tese (Doutorado em Ciência Florestal) - Departamento de Engenharia Florestal, Universidade Federal do Paraná, Curitiba-PR. 2001.

TABARÉS, J. L. M.; ORTIZ, L.; GRANADA, E.; VIAR, F. P. Feasibility study of energy use for densified lignocellulosic materials (briquettes).Ed. Elsevier Science Ltd. Fuel. v. 79, n. 10. p. 1229 1237. 2000.

THEK, G.; OBENBERG, I. Wood pellet production osts under Austrian and comparison to Swedish framework conditions.Proceedings of the $1^{\text {st }}$ Conference on Pellets. Stockholm, Sweden. 2002.

TRIPATHI, A. K.; IVER, P. V. R.; KANDPAL, T. C. A. Techno-economic evaluation of biomass briquetting in India. Biomass and Bioenergy. v. 14, n. 5/6. p. 479 - 488. Great Britain. 1998. 